\title{
Konjungtivitis pada Bayi (Oftalmia Neonatorum)
}

\section{Chelsea T. J. M. Pratasik, ${ }^{1}$ Imelda H. M. Najoan, ${ }^{2}$ Rillya D. P. Manoppo}

\author{
${ }^{1}$ Program Studi Pendidikan Dokter Fakultas Kedokteran Universitas Sam Ratulangi, Manado, \\ Sulawesi Utara, Indonesia \\ ${ }^{2}$ Bagian Ilmu Kesehatan Mata Fakultas Kedokteran Universitas Sam Ratulangi, Manado, \\ Sulawesi Utara, Indonesia \\ Email: chelseapratasik99@gmail.com
}

\begin{abstract}
Conjunctivitis is a disease that can affect every age group including newborns. One of its complications is blindness. The vision of WHO in 2020 is ophthalmia neonatorum as the leading cause of blindness in low income country in African and other third world countries. This study was aimed to obtain an overview of ophthalmia neonatorum in general. This was a literature review study using three database Clinical Key, Pub Med, and Google Scholar, using the key words ophthalmia neonatorum OR neonatal conjunctivitis. The result showed that the most common pathogens were $S$. aureus, $C$. trachomatis, and $N$. gonorrhoeae. Transmission through normal labour had the highest incidence of conjunctivitis in newborns. Internal factors of mothers such as infected by pathogens had a tendency to transmit the infection to the babies meanwhile external factors of mothers were skipping the initial antenatal care (ANC) for screening of pathogens infecting the mothers supported by the high prevalence of conjunctivitis in developing countries associated with lower educational and socioeconomic status. In conclusion, ophthalmia neonatorum was affected by the mother conditiom (antenatal infection) and external factors including ANC, developed countries, and low educational and socioeconomic status.
\end{abstract}

Keywords: conjunctivitis, newborns, ophthalmia neonatorum

\begin{abstract}
Abstrak: Konjungtivitis merupakan penyakit mata yang dapat menyerang semua kalangan termasuk bayi. Salah satu komplikasi konjungtivitis pada bayi ialah kebutaan. World Health Organization tahun 2020 mencanangkan bahwa oftalmia neonatorum termasuk salah satu penyebab utama terjadinya kebutaan di negara-negara yang berpenghasilan rendah di benua Afrika dan negara lainnya. Penelitian ini bertujuan untuk mendapatkan gambaran umum dari konjungtivitis pada bayi. Jenis penelitian ialah literature review. Pencarian data menggunakan tiga database, yaitu: ClinicalKey, PubMed, dan Google Scholar. Kata kunci yang digunakan yaitu ophthalmia neonatorum OR neonatal conjunctivitis. Hasil penelitian mendapatkan bahwa organisme patogen penyebab tersering ialah S. aureus, C. trachomatis, dan N. gonorrhoeae dengan penularan melalui jalan lahir ibu yang terinfeksi. Persalinan pervaginam menunjukkan angka kejadian terjadinya konjungtivitis pada bayi yang tinggi. Faktor internal ibu yang terinfeksi organisme patogen berisiko menularkan infeksi kepada bayinya. Faktor eksternal ibu yang tidak rutin melakukan antenatal care (ANC) akan melewatkan skrining awal adanya organisme yang menginfeksi ibu, didukung juga oleh prevalensi konjungtivitis yang terjadi di negara berkembang dengan status pendidikan dan sosioekonomi yang masih rendah. Simpulan penelitian ini ialah konjungtivitis pada bayi dipengaruhi oleh faktor ibu (infeksi antenatal) dan faktor eksternal termasuk ANC, negara berkembang, serta status pendidikan dan sosioeknomi yang rendah.
\end{abstract}

Kata kunci: konjungtivitis, bayi, oftalmia neonatorum

\section{PENDAHULUAN}

Mata adalah 'jendela dunia'. Mata me- rupakan salah satu organ yang memiliki peran penting bagi tubuh, terutama sebagai 
indera penglihatan. Mata dapat terkena berbagai kondisi, dari yang bersifat primer sampai sekunder akibat kelainan pada sistem organ tubuh lainnya.

Untuk menjalankan fungsinya, mata ditunjang oleh berbagai struktur termasuk konjungtiva sebagai struktur terluarnya. Oleh karena itu, konjungtiva sangat rentan terpapar bahan, zat, atau agen asing yang memicu terjadinya infeksi. ${ }^{1}$ Infeksi yang biasanya terjadi pada mata paling rentan mengenai konjungtiva, disebut konjungtivitis. Penyakit konjungtivits saat ini berada pada peringkat ke-3 penyakit mata terbesar di dunia setelah penyakit katarak dan glaukoma. ${ }^{2}$ Konjungtivitis dapat terjadi pada berbagai kalangan, bisa menyerang orang dewasa, anak, bahkan bayi. ${ }^{3}$

Infeksi konjungtiva pada bayi dikenal sebagai oftalmia neonatorum, pertama kali dijelaskan pada tahun 1750 bahwa penyakit ini terjadi pada bayi baru lahir selama bulan pertama kehidupan. ${ }^{4-6}$ Penyakit ini menunjukkan tanda-tanda klinis seperti eritema, edema kelopak mata dan konjungtiva palpebra, serta adanya sekret mukopurulen. Penyebab utama dari konjungtivitis pada bayi bisa secara septik (infeksi karena bakteri dan virus) maupun aseptik (infeksi karena agen kimiawi, antara lain oleh penggunaan profilaksis antibiotik dan larutan perak nitrat.,

Patogen yang menyebabkan infeksi bervariasi secara geografis, dikarenakan perbedaan prevalensi infeksi yang terjadi pada ibu dari bayi. Mayoritas konjungtivitis pada bayi yang menular disebabkan oleh bakteri. Biasanya organisme menginfeksi bayi melalui kontak langsung selama proses kelahiran. Infeksi dalam jalan lahir dapat naik ke uterus sehingga bayi yang dilahirkan melalui bedah sesar juga dapat terinfeksi. Kemungkinan ini diperkuat oleh kejadian ketuban pecah dini pada persalinan lama. ${ }^{7}$

Umumnya kasus konjungtivitis dapat sembuh sendiri tetapi beberapa di antaranya bisa berkembang menjadi komplikasi serius. Salah satu kompilkasi konjungtivitis pada bayi yang menyebabkan kebutaan pada sekitar 10.000 bayi setiap tahun di dunia. Melalui "The Right to Sight Global Initiative for the Elimination of Avoidable Blindness" tahun 2020, WHO mencanangkan bahwa oftalmia neonatorum termasuk sebagai salah satu penyebab utama terjadinya kebutaan di negara-negara berpenghasilan rendah di benua Afrika dan negara berkembang di benua lain. ${ }^{8}$ Berdasarkan hal tersebut maka penulis tertarik untuk meneliti gambaran terjadinya konjungtivitis pada bayi secara umum.

\section{METODE PENELITIAN}

Penelitian ini menggunakan rancangan metode literature review. Pencarian data berupa jurnal penelitian dengan menggunakan tiga database yaitu PubMed, ClinicalKey, dan Google Scholar. Kata kunci yang digunakan dalam pencarian yaitu neonatal conjunctivitis, OR, dan ophthalmia neonatorum.

\section{HASIL PENELITIAN}

Dalam pencarian kata kunci menggunakan tiga database didapatkan 13.693 jurnal. kemudian dilakukan skrining berdasarkan judul yang sesuai sesuai dengan tema literature review didapatkan 52 artikel. Selanjutnya 52 jurnal tersebut diskrining abstrak dan fulltext-nya berdasarkan kriteria inklusi dan ekslusi dan didapatkan 10 jurnal yang memenuhi kriteria inklusi, terdiri dari 6 penelitian potong lintang, 2 penelitian kohort, dan 2 penelitian prospektif observasional (Tabel 1). Literatur yang dipakai melibatkan penelitian pada bayi baru lahir dan ibu bayi tersebut sebagai sampel. Jumlah sampel yang diambil berkisar ratusan sampai ribuan.

Tabel 1. Hasil kajian literatur yang digunakan dalam penelitian

\begin{tabular}{llllll}
\hline \multicolumn{1}{c}{ Peneliti, Tahun } & Negara & N & Metode Pemeriksaan & Hasil telaah \\
\hline $\begin{array}{llll}\text { Pourabbas et } \\
2018^{9}\end{array}$ & & Iran & 239 & Penelitian pada spesi- & Ibu yang melahirkan dengan SVD: CT \\
& & & men konjungtiva dan & 37, NG 3. Bayi: CT 28, NG 1. Tingkat \\
& & & & endoserviks dari ibu penularan infeksi pada bayi yang lahir \\
\hline
\end{tabular}




\begin{tabular}{|c|c|c|c|}
\hline & & & $\begin{array}{l}\text { serta bayinya, diidenti- } \\
\text { fikasi dengan PCR }\end{array}$ \\
\hline Afjeiee et al, $2013^{10}$ & Iran & 2253 & $\begin{array}{l}\text { Penelitian pada spesi- } \\
\text { men konjungtiva dari } \\
2.253 \text { bayi, identifikasi } \\
\text { dengan pewarnaan } \\
\text { Gram, kultur bakteri, } \\
\text { dan PCR. }\end{array}$ \\
\hline Kakar et al, $2010^{11}$ & India & 58 & $\begin{array}{l}\text { Penelitian pada spesi- } \\
\text { men konjungtiva dari } \\
58 \text { bayi yang baru lahir } \\
\text { yang memiliki sekret } \\
\text { mata, diagnosis labora- } \\
\text { torium dengan kultur } \\
\text { bakteri, pewarnaan } \\
\text { Gram, dan pewarnaan } \\
\text { antibodi fluoresens } \\
\text { langsung (DFA) }\end{array}$ \\
\hline
\end{tabular}

Wadhwani et al, India $300 \quad$ Penelitian pada $300 \mathrm{ibu}$ $2011^{12}$ dari ibu yang terinfeksi: CT 28/37 $(75,6 \%), \mathrm{NG} 1 / 3$.

Total sampel 2253 bayi didapatkan 194 bayi konjungtivitis (+).

Untuk organisme penyebab tersering didominasi Staphylococcus koagulase negatif sebesar 130 kasus (53.9\%) diikuti KP 6.6\%, NG 3.7\%. Tidak terdapat hubungan bermakna antara kejadian konjungtivitis pada bayi dengan jenis kelamin $(\mathrm{p}=0,14)$, model persalinan $(\mathrm{p}=0,11)$, dan riwayat ketuban pecah dini $(\mathrm{p}=0,05)$

58 bayi konjungtivitis (+) yang diperiksa menunjukkan sel nanah 22 $(37,9 \%)$, CT $18(31 \%)$, KP $10(17,2 \%)$, SA $4(6,9 \%)$, S $4(6,9 \%)$.

Khusus untuk CT dilakukan DFA dengan:

- Usia bayi $\leq 7$ hari: (+) $12>7$ hari: (+) $6(\mathrm{p}=0,901)$

- jenis kelamin L: (+) 10 P: (+) 8 $(\mathrm{p}=0,138)$

- BBLR: Ya (+) 10 Tidak (+) 8 $(\mathrm{p}=0,284)$

- Preterm Ya (+) $6(27,3 \%)$ Tidak (+) $12(33,3 \%)(\mathrm{p}=0,628)$

- Persalinan SVD (+) 13 (37.1\%) CS (+) $5(21.7 \%)(\mathrm{P}=0.214)$.

Tidak ditemukan adanya hubungan bermakna antara demografi dengan terjadinya konjungtivitis.

- Bayi

Grup A: NGr 61\%, NP 14\%, PO: Coagulase negative staphylococcus 40 (20\%), $\alpha$-Hemolytic streptococcus 1 SA 4, Ps 1, EC 4. Grup B: NGr 59\%, NP 15\%, PO: Coagulase negative staphylococcus $21(21 \%), \alpha$-Hemolytic streptococcus 2 , SA 1, EC 2 .

- Ibu

Grup A: NGr 10,5\%, NP 49,5\%, PO: Coagulase negative staphylococcus 53 (26,5\%), Cs 4, SA 4, EC 16, Ks 3.

Grup B: NGr 49,5\%, NP 21\%, PO: Coagulase negative staphylococcus 66 (33\%), $\alpha$ - Hemolytic streptococcus, Cs 1 , EC 6, Ks 1 .

- 5 bayi dari Grup A konjungtivitis (+) dengan bakteri Coagulase negative staphylococcus (4), SA (1).

Terdapat hubungan bermakna ibu dengan riwayat saluran genital terinfeksi dengan terjadinya konjungtivitis pada bayinya $(\mathrm{p}<0,000)$

Honkila et al, 2018 $\quad$ Finland $490 \quad$ Pengambilan spesimen konjungtiva 167 untuk multiple PCR deteksi virus pernapasan, 163 untuk PCR deteksi CT
- 167: 8 Konjungtivitis (+) dengan RV 4, AV 3, BV 1.

- 163: Konjungtivitis (-).

- 160: 58 Konjungtivitis (+) dengan SA 25 (16\%), MC 15 (9.4\%), Cs 6 


\begin{tabular}{|c|c|c|c|c|}
\hline & & & $\begin{array}{l}\text { \& NG, dan } 160 \text { untuk } \\
\text { kultur bakteri. }\end{array}$ & $\begin{array}{l}\text { (3,8\%), SP } 6(3,1 \%) \text {, HI } 4(2,5 \%) \text {, } \\
\text { BC } 1(0,6 \%) \text {, EC } 1(0,6 \%) \text {. } \\
\text { Gejala yang terjadi pada bayi: } 58 \\
\text { bayi konjungtivitis bakteri: sekret } \\
\text { mukopurulen } 54(93 \%) \text {, kemerahan } \\
16(28 \%) \text {, bengkak } 20(34 \%) \text {, } \\
\text { rhinorrhea } 12(21 \%) \text {, batuk } 2(3 \%) \text {, } \\
\text { bersin } 1(2 \%)(\mathrm{p}>0.05) \\
\text { Tidak ditemukan adanya hubungan } \\
\text { bermakna antara gejala konjungtivitis } \\
\text { dengan temuan organisme pada peme- } \\
\text { riksaan (p>0,05) }\end{array}$ \\
\hline Shireen et al, $2010^{14}$ & Pakistan & 1010 & $\begin{array}{l}\text { Bayi yang lahir diamati } \\
\text { dan diperiksa adanya } \\
\text { gejala konjungtivitis } \\
\text { yang timbul. Jika me- } \\
\text { nunjukkan gejala, di- } \\
\text { ambil sampel konjung- } \\
\text { tiva dan diperiksa de- } \\
\text { ngan pewarnaan Gram, } \\
\text { kultur bakteri, frekuen- } \\
\text { si faktor risiko dari ibu } \\
\text { dan bayi ikut dinilai. }\end{array}$ & 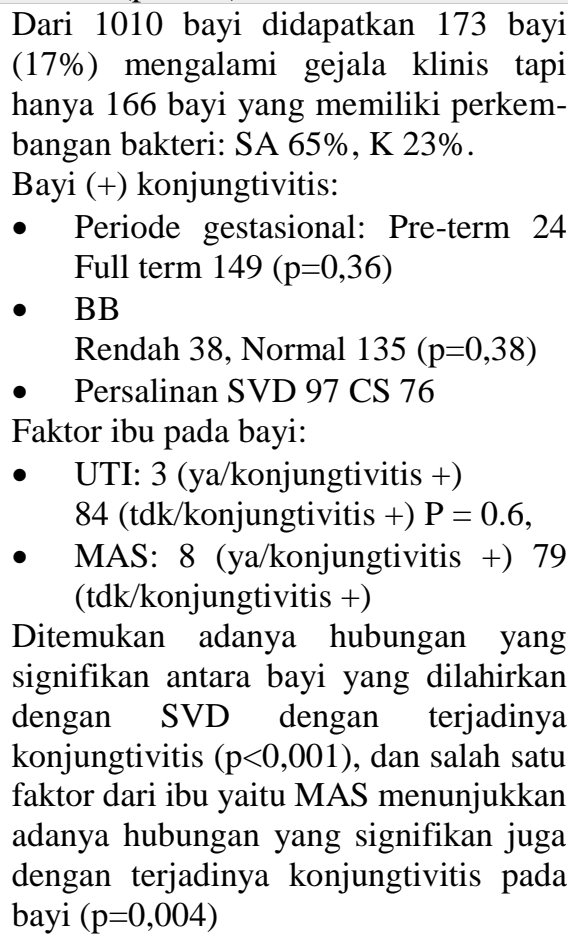 \\
\hline Msukwa et al, $2014^{15}$ & Malawi & 231 & $\begin{array}{l}\text { Penelitian mengguna- } \\
\text { kan rekam medis dari } \\
231 \text { bayi yang terdiag- } \\
\text { nosis konjungtivitis. } \\
\text { Frekuensi dihitung dari } \\
\text { berbagai faktor risiko } \\
\text { pada bayi dengan } \\
\text { konjungtivitis dan ibu } \\
\text { mereka. }\end{array}$ & $\begin{array}{l}\text { - Bayi konjungtivitis (+): jenis } \\
\text { kelamin L 58\% P 42\%, preterm } \\
80 \% \text {, persalinan SVD 13\% CS } 7 \% \text {. } \\
\text { Faktor risiko ibu: PROM 56, sepsis } \\
\text { selama persalinan/op 20, Riwayat } \\
\text { IMS 15, Pre-eklampsia 14, Anemia } \\
12(5 \%) \text {, Demam } 10 \text { (4\%), Trauma } \\
\text { persalinan } 10(4 \%) \text {. Faktor Bayi: } \\
\text { APGAR score<7 43, Demam 17, } \\
\text { Aspirasi meconium } 12 \text {. } \\
\text { Berdasarkan distribusi frekuensi ter- } \\
\text { banyak didaptkan adanya hubungan } \\
\text { antara faktor risiko pada bayi maupun } \\
\text { ibu dengan terjadinya konjungtivitis. }\end{array}$ \\
\hline $\begin{array}{l}\text { Ayebazibwe et al, } \\
2015^{16}\end{array}$ & Uganda & 438 & $\begin{array}{l}\text { Pengamatan pada bayi } \\
\text { baru lahir ( } 28 \text { hari) } \\
\text { sampai menunjukkan } \\
\text { tanda klinis, bayi yang } \\
\text { menunjukkan tanda } \\
\text { klinis konjungtivitis } \\
\text { diambil sampel dari } \\
\text { konjungtiva dan dipe- } \\
\text { riksa. }\end{array}$ & $\begin{array}{l}\text { Bayi: persalinan SVD } 338(77.2 \%) \text { CS } \\
110(22,8 \%), 49 \text { bayi menunjukkan } \\
\text { gejala klinis konjungtivitis dengan } 34 \\
\text { kultur(+), } 14 \text { kultur(-), } 1 \text { terkontaminasi. } \\
34 \text { bayi dengan kultur (+): SA } 23 \\
(67,7 \%), \mathrm{KP} 7, \mathrm{NG} \mathrm{3,} \mathrm{SPG} 1.59 \text { bayi } \\
\text { menerima profilaksis dalam } 24 \text { jam } \\
\text { kelahiran, } 389 \text { bayi tidak. } \\
\text { Ibu: primigravida } 164(37,4 \%) \text { multi- } \\
\text { gravida } 284(62,6 \%) \text {, infeksi urogenital } \\
99(22,6 \%), \text { PROM } 72(16,4 \%) \text {. }\end{array}$ \\
\hline
\end{tabular}




\begin{tabular}{|c|c|c|c|}
\hline $\begin{array}{l}\text { Khoshdel et al, } \\
2012^{17}\end{array}$ & Iran & 5206 & $\begin{array}{l}\text { Pengambilan spesimen } \\
\text { konjungtiva dan dipe- } \\
\text { riksa, diagnosis labora- } \\
\text { torium pewarnaan } \\
\text { Gram, kultur bakteri, } \\
\text { ELISA untuk CT dan } \\
\text { pemeriksaan immu- } \\
\text { nofluoresent tidak } \\
\text { langsung }\end{array}$ \\
\hline $\begin{array}{l}\text { Mohammed et al, } \\
2013^{18}\end{array}$ & Nigeria & 175 & $\begin{array}{l}\text { Pengambilan spesimen } \\
\text { konjungtiva pada bayi } \\
\text { baru lahir, diagnosis } \\
\text { laboratorium dengan } \\
\text { pewarnaan Gram, ICT } \\
\text { untuk antigen Chla- } \\
\text { mydia. }\end{array}$ \\
\hline
\end{tabular}

Didapatkan nilai OR tertinggi 4,85 yaitu tidak dilakukakn pemberian profilaksis pada bayi berpeluang 4,85 kali lebih besar bayi terkena konjungtivitis, dan ibu yang tidak melakukan ANC memiliki nilai OR 0,70 bepeluang 0,70 kali bisa menyebabkan bayi mereka terjadi konjungtivitis

Dari total sampel 5206 bayi didapatkan 162 konjungtivitis (+) dengan coagulase negative SA 49, coagulase positive SA 23, SP 21, EC 16, Enterobacter 12, K 5 , P 2, HI 3, NG 9, CT 22 (13,6\%). Bayi yang lahir dengan persalinan SVD $45 \%$, CS 55\%.

Adanya hubungan bermakna yang didapatkan dari beberapa faktor dengan terjadinya konjungtivitis pada bayi yaitu, model persalinan $(\mathrm{p}<0,006)$, infeksi pre-natal $(\mathrm{p}<0,001)$.

Dari 175 sampel didapatkan konjungtivitis (+) SA $53(29,7 \%)$, EC 23 $(13,1 \%)$, Chlamydia $5(2,9 \%)$, K 3 $(1,7 \%)$, P $11(6,3 \%)$, NG $3(1,7 \%)$, tidak ada pertumbuhan $78(44,6 \%)$.

Didapatkan adanya hubungan bermakna antara terjadinya konjungtivitis dengan tingkat pendidikan ibu $(\mathrm{p}=0,003)$, kurangnya kehadiran saat ANC $(\mathrm{p}=0,021)$, dan status ekonomi rendah $(\mathrm{p}=0,017)$

SVD Spontaneous Vaginal Delivery; CS Caesarean Section; CT Chlamydia Trachomatis; NG Neisseria Gonorrhoeae; PROM Premature Rupture of Membrane; KP Klebsiella Pneumonia; CD Corynebacterium Diphtheriae; SA Staphylococcus Aureus; S Staphylococcus; NGr No Growth; NP No Pathogenic Organisms; PO Pathogenic Organisms; P Pseudomonas; E Escherichia Coli; K Klebsiella; RV Rhinovirus; AV Adenovirus; BV Bocavirus; MC Moraxella catarrhalis; Cs Corynebacterium species; SP Streptococcus Pneumoniae; HI Haemophilus influenzae; BC Bacillus cereus; K Klebsiella; UTI Urinary Tract Infection; VD Vaginal Discharge; MAS Meconium aspiration syndrome; IMS Infeksi Menular Seksual; SPG Streptococcus Pyogenes; ANC Antenatal Care

\section{BAHASAN}

Konjungtivitis pada bayi (oftaltmia neonatorum) terjadi pada bayi baru lahir dalam kurun waktu 28 hari. Kejadian ini bisa disebabkan oleh agen infeksius biasanya berupa bakteri dan virus tetapi bisa juga oleh agen non-infeksius agen kimiawi.

Perkembangan mikroogranisme yang paling sering dilaporkan menyebabkan konjungtivitis pada bayi ialah bakteri Chlamydia trachomatis dan Neisseria gonorrhoeae, tetapi berdasarkan hasil bahasan beberapa literatur didapatkan bahwa bakteri Staphylococcus yang lebih mendominasi dibandingkan kedua bakteri tersebut. Menurut penelitian Afjeiee et $\mathrm{al}^{10}$ tahun di
Iran, bakteri Staphylococcus koagulase negatif menunjukkan frekuensi 53,9\% dari kasus kojungtivitis dibandingkan $N$. gonorrhoeae yang hanya sebesar $3,7 \%,{ }^{11}$ Demikian pula dengan penelitian Wadhwani et $\mathrm{al}^{12}$ di India yang menunjukkan perkembangan bakteri Staphylococcus sebagai penyebab dari hampir setengah kasus konjungtivitis pada bayi..

Infeksi konjungtiva yang terjadi pada bayi biasanya diperoleh dari ibu. Bayi dengan konjungtivitis terinfeksi oganisme tertentu, paling sering karena jalan lahir dari ibu yang terinfeksi. Pada penelitian Shireen et al $^{14}$ di Pakistan tahun 2010 didapatkan sebanyak 97 bayi yang lahir normal dengan 
persalinan pervaginam menderita konjungtivitis; hal ini didukung dengan oleh nilai $\mathrm{p}<0,001$ yang menunjukkan hubungan bermakna antara keduanya. Menurut Khoshdel $^{17}$ di Iran terdapat hubungan bermakna antara model persalinan baik persalinan pervaginam maupun operasi sesar dengan konjungtivitis yang didukung dengan nilai $\mathrm{p}<0,006$.

Penelitian Pourabbas et $\mathrm{al}^{9}$ tahun 2018 di Iran menemukan bahwa sebanyak 28 dari 37 ibu $(75,6 \%)$ yang terinfeksi C. trachomatis menularkan infeksi kepada bayinya yang baru lahir, dan sebanyak 1 dari 3 ibu yang terinfeksi Neisseria gonorrhoeae menyebabkan bayinya terinfeksi. Menurut Wadhwani et $\mathrm{al}^{12}$ temuan konjungtivitis pada bayi kemungkinan berasal dari infeksi saluran urogenital ibu dengan nilai $p<0,000$ yang menunjukkan terdapatnya hubungan bermakna.

Penelitian oleh Khoshdel et al ${ }^{17}$ di Iran mendapatkan adanya hubungan bermakna antara infeksi pre-natal pada ibu dengan perkembangan konjungtivitis $(\mathrm{p}<0,001)$. Beranjak ke Nigeria, penelitian oleh Mohammed et al ${ }^{18}$ menyatakan adanya hubungan bermakna $(\mathrm{p}=0,001)$ antara ibu dengan riwayat pecah ketuban sebelum waktunya dan terjadinya konjungtivitis pada bayi.

Kehadiran ibu dalam perawatan kehamilan (antenatal care) sangat penting untuk mengontrol perkembangan janin yang sehat, terlebih juga dalam perawatan ibu saat hamil dapat mencengah terjadinya masalahmasalah serius yang nantinya berdampak serius pula pada bayi. Salah satu penyebab konjungtivitis pada bayi ialah ketidakikutsertaan ibu dalam perawatan selama kehamilan. Hal ini menyebabkan tidak terlaksananya skrining awal yang baik untuk mendeteksi adanya berbagai organisme yang dapat menginfeksi ibu. Ibu dengan riwayat infeksi menular seksual merupakan salah satu faktor yang dapat menyebabkan infeksi pada bayinya. Penelitian oleh Mohammed et al ${ }^{18}$ di Nigeria juga menegaskan bahwa terdapat hubungan bermakna antara kurang maupun ketidakhadiran saat perawatan selama kehamilan dengan terjadinya konjungtivitis pada bayi $(\mathrm{p}=0,021)$.
Prevalensi kejadian konjungtivitis mayoritas terjadi di negara-negara berkembang karena masih kurangnya pengetahuan serta faktor sosial ekonomi yang tergolong rendah merupakan alasan sehingga banyak ibu hamil yang tidak memeriksakan kandungannya untuk mendapatkan perawatan yang lebih baik.

\section{SIMPULAN}

Penularan organisme dari ibu yang terinfeksi merupakan faktor yang berpotensi tinggi menyebabkan konjungtivitis pada bayi. Tidak dilakukannya skrining awal pada ibu hamil juga turut berpengaruh terhadap terjadinya konjungtivitis pada bayi. Prevalensi yang tinggi konjungtivitis pada bayi di negara berkembang lebih tinggi dibandingkan negara maju ditinjau berdasarkan mayoritas status pendidikan dan sosioekonomi yang tergolong masih rendah.

\section{Konflik Kepentingan}

Penulis menyatakan tidak terdapat konflik kepentingan dalam studi ini.

\section{DAFTAR PUSTAKA}

1. Shumway CL, Mothlagh M, Wade M. Anatomy, Head and Neck, Eye Conjunctiva. StatPearls. 2018. Available from: http: //www.ncbi.nlm.nih.gov.pubmed/30137 787

2. Gilbert C. Viral conjunctivitis Adenoviral conjunctivitis. Community Eye Health J. 2015; 18(53):12-25.

3. Chaberny IF, Schnitzler P, Geiss HK, Wendt C. An outbreak of epidemic keratoconjunctivitis in a pediatric unit due to adenovirus type 8. Infect Control Hosp Epidemiol. 2003;24(7):514-9.

4. Mallika PS, Asok T, Faisal HA, Aziz S, Tan AK, Intan G. Neonatal conjunctivitis - a review. Malaysian Fam Physician. 2008;3(2):77-81.

5. Iyamu E, Enabulele O. A survey on ophthalmia neonatorum in Benin City, Nigeria (Emphasis on gonococcal ophthalmia). Online J Health Allied Sci. 2003;2(2):49.

6. Bankes JLK. Clinical Ophthalmology. Br J Ophthalmol. 1985;69:154.

7. Abazi F, Kubati M, Berisha B, Gashi M, Kocinaj D, Krasniqi X, et al. Ophtalmia 
neonatorum. conjunctivitis - a complex multifaceted disord. 2011. Available from: https://www.intechopen.com/ books/conjunctivitis-a-complex-andmultifaceted-disorder/ophtalmianeonatorum

8. Gilbert C, Foster A. Childhood blindness in the context of VISION 2020 - The right to sight. Bull World Health Organ. 2001; 79(3):227-32

9. Pourabbas B, Rezaei Z, Mardaneh J, Shahian M, Alborzi A. Prevalence of Chlamydia trachomatis and Neisseria gonorrhoeae infections among pregnant women and eye colonization of their neonates at birth time, Shiraz, Southern Iran. BMC Infect Dis. 2018;18(1):1-4.

10. Afjeiee SA, Tabatabaei SR, Fallah F, Fard AT, Shiva $\mathrm{F}$, Adabian $\mathrm{S}$, et al. A microbiological study of neonatal conjunctivitis in two hospitals in Tehran, Iran. Asian Pacific J Trop Dis. 2013;3(6): 429-33.

11. Kakar S, Bhalla P, Maria A, Rana M, Chawla $\mathrm{R}$, Mathur NB, et al. Chlamydia trachomatis causing neonatal conjunctivitis in a tertiary care center. Indian $\mathrm{J}$ Med Microbiol. 2010;28(1):457.

12. Wadhwani M, D'Souza P, Jain R, Dutta R, Saili A, Singh A, et al. Conjunctivitis in the newborn- A comparative study. Indian J Pathol Microbiol. 2011;54(2): 254-7.
13. Palareti G, Legnani C, Cosmi B, Antonucci E, Erba N, Poli D, et al. Comparison between different D-Dimer cutoff values to assess the individual risk of recurrent venous thromboembolism: Analysis of results obtained in the DULCIS study. Int $\mathbf{J}$ Lab Hematol. 2016;38(1):42-9.

14. Shireen Gul S, Jamal M, Khan N. Ophthalmia neonatorum. Can Med Assoc J. 2020; 72(8):576-80.

15. Msukwa G, Batumba N, Drucker M, Menezes L, Ranjit R. Maternal and neonatal risk factors associated with vertical transmission of ophthalmia neonatorum in neonates receiving health care in Blantyre, Malawi. Middle East Afr J Ophthalmol. 2014;21(3):240-3.

16. Ayebazibwe B, Twinamasko A, Waddell K. Incidence of neonatal conjunctivitis at Mbarara Regional Referral Hospital , South Western Uganda. J Ophthalmol East Cent South Africa. 2015;85(13): 50-6.

17. Khoshdel A. Incidence and bacteriological profile of neonatal conjuctivitis in Hajar Hospital, Shahrekord, Iran. Iran J Pathol. 2012;7(2):86-91.

18. Mohammed A, Mustafa A, Ibrahim M, Ihesiulor U. Maternal risk factors for neonatal conjunctivitis in Aminu Kano Teaching Hospital, Kano, Nigeria. Niger J Basic Clin Sci. 2013;10(2):60. 